\section{Acknowledgments}

The author thanks Francine Cournos, M.D., Maureen Empfield, M.D., Ewald Horwath, M.D., and Martin Kramer, M.D., for information about the medical and psychiatric aspects of HIV, and Robin Goldman, J.D., for assistance in developing the legal analysis.

\section{References}

1. Kelley KV: AIDS and ethics: an overview. General Hospital Psychiatry 9:331-340, 1987

2. Gosten L: Public health strategies for confronting AIDS: legislative and regulatory policy in the United States. JAMA 261:1621-1630, 1989

3. Binder R: AIDS antibody tests on inpatient psychiatric units. American Journal of Psychiatry 144:176-181, 1987

4. Article 4419b-1, Vernon's Texas Civil Statutes, Section 9.02 (1987)

5. $146.025(2)(a)$, Wisconsin Statutes (1987-1988)

6. Guardianship of Anthony, 402 Mass 723 (Sup Ct Mass, 1988)
7. Centers for Disease Control: Update: universal precautions for prevention of transmission of human immunodeficiency virus, hepatitis B virus, and other bloodborne pathogens in health care settings. Morbidity and Mortality Weekly Report 37:377-382, 1988

8. Section 413, New York Social Service Law (McKinney, 1978)

9. AIDS policy: guidelines for inpatient psychiatric units. American Journal of Psychiatry 145:542, 1988

10. Gostin L, Curran WJ: Legal control measures for AIDS: reporting requirements, surveillance, quarantine, and regulation of public meeting places. American Journal of Public Health 77:214218,1987

11. Griswald v Connecticut, 381 US 479 (1966)

12. Rehabilitation Act of 1973,29 USC 701 (1973)

13. Tarasoff $v$ Regents of the University of California, 551 P2d 334 (Cal Sup Ct, 1976)

14. Naidu v Laird, 539 A2d 1064 (Del Sup Ct, 1988)

15. Holbrook T: Policing sexuality in a modern state hospital. Hospital and Community Psychiatry 40:75-79, 1989
16. Cournos F, Empfield M, Horwath E, et al: The management of HIV infection in state psychiatric hospitals. Hospital and Community Psychiatry 40:153-157, 1989

17. Article 27-F, New York Public Health Law (McKinney, 1988)

18. Centers for Disease Control: Recommendations for prevention of HIV transmission in health-care settings. Morbidity and Mortality Weekly Report 36:15-17, 1988

19. Glover $v$ East Neb Comm, Office of Retardation. 686 F Supp 243 (DC Neb, 1988)

20. Doe v County of Cook, Illinois (DC N Ill 87-C-68888, Feb 24, 1988)

21. School Board of Nassau County v Arline, 94 L ED 2d 307 at 318.319 (1987)

22. APA position statements outline role of psychiatrists in combating fear of AIDS. Hospital and Community Psychiatry $38: 433,1987$

23. Appelbaum PS: AIDS, psychiatry, and the law. Hospital and Community Psychiatry 39:13-14, 1988

24. Cournos F, Horwath E: Confining AIDS Patients (ltr). Hospital and Community Psychiatry 39:671, 1988

\title{
Involuntary Medication and the Case of Joyce Brown
}

\section{Francine Cournos, M.D.}

In October 1987, Joyce Brown became the first bomeless person removed from New York City's streets and bospitalized under a city initiative that authorized evaluation of "gravely disabled" bomeless persons for admission to inpatient psychiatric treatment. Miss Brown's highly publicized and ultimately successful court battle to prevent a course of forced

Dr. Cournos is assistant clinical professor of psychiatry at Columbia University College of Physicians and Surgeons and director of the Washington Heights Community Service of the New York State Psychiatric Institute, 722 West 168th Street, New York, New York 10032. medication is described. Her refusal of medication was upheld based on ber capacity to understand the proposed treatment and to express a partially rational opinion about it. The autbor, who served as independent psychiatric consultant to the court on the decision about Miss Brown's involuntary medication, uses the case to illustrate some of the problems of involuntary psychiatric intervention, including the commitment of competent patients and the lack of a coberent approach to persistent treatment refusal.

The problem of involuntary treatment recently received worldwide attention when a patient named Joyce Brown challenged New York City's widely publicized plan to forcibly hospitalize and treat mentally ill homeless people who were living on the streets and refusing mental health services.

In October 1987, a team of mental health workers from Project HELP were authorized by a liberalized interpretation of New York State's long-standing civil commitment statutes to remove certain "gravely disabled" individuals from the streets (1). These individuals were to be brought to Bellevue Hospital, where they could be evaluated for admission to a special psychiatric ward. Joyce Brown was the first homeless person to be hospitalized as a result of the Project HELP initiative. Rarely has a case of involuntary psychiatric intervention inspired such wide public attention, suggesting that the public has become increasingly interested in whether forced psychiatric care is the 
proper response to certain kinds of homelessness.

I acted as independent psychiatric consultant to the court on the decision of whether Joyce Brown, a committed patient, could be subjected to a course of involuntarily administered antipsychotic drugs. In this paper I examine some of the issues and conflicts involved in that decision.

\section{Case developments}

Joyce Brown's bospitalization. Joyce Brown, who initially identified herself as Billie Boggs, was a 40-year-old single black woman who had been living on the streets of an affluent Manhattan neighborhood for a year and a half, panhandling to get enough money for food. On October 28, 1987, she was picked up by Project HELP (2). She was taken to Bellevue Hospital's emergency room, committed at Bellevue, and admitted to the special unit for the homeless.

Popular attention was focused on two questions. First, was Joyce Brown homeless because she was poor or because she was mentally ill? And second, should we praise the efforts of the city to remove her from her debased circumstances or support her struggle to assert her individual rights in the face of overwhelming state power? But while the media focus on Joyce Brown may have made her appear typical of the homeless mentally ill entering New York City's new program, her case was in fact not representative at all. She was probably less impaired than most chronic mentally ill persons. She was also virtually unique in her capacity to reconstitute herself (3).

Legal proceedings. Miss Brown's case became the object of three widely publicized court proceedings during which her counsel, on her behalf, waived all of her rights of confidentiality. Thus the information in this paper about Miss Brown comes from the public record.

On October 29, 1987, Miss Brown petitioned for a hearing to protest her commitment. At the subsequent series of hearings, two entirely different accounts of her situation emerged. Lawyers for the city and their psychiatric experts argued that Miss Brown had schizophrenia, was delusional, and required hospitalization because she represented a danger to herself by virtue of self-neglect, provocative behavior, and suicidal impulses. Miss Brown's lawyers, who were members of the New York Civil Liberties Union (NYCLU), and their psychiatric consultants asserted that Miss Brown did not have a serious mental illness, but was a "professional street person" whose difficulties on the street were a natural consequence of being homeless. They pointed to her ability to survive on the streets without harming herself or other people.

The two accounts of Miss Brown were as different as her own appearance under varying circumstances. On the streets, she was dirty, disheveled, malodorous, hostile, and verbally abusive. In court, she was well-groomed, in control, logical, coherent, and even witty.

The trial judge, faced with entirely contradictory testimony by psychiatrists, gave considerable weight to Miss Brown's rational demeanor and testimony at the time of the hearing. He ruled that she did not meet the standard for commitment and ordered her released on November 12, 1987 (4). The city immediately appealed this decision, and Miss Brown remained hospitalized during the appeal. On December 18, 1987, in a 3-to-2 decision, the appellate division of the state supreme court reversed the trial court and upheld her commitment, citing the failure of the trial judge to give sufficient weight to the testimony of the treating psychiatrists (5).

Miss Brown's hospitalization was continued, but she had consistently refused medication. In New York State, since the Rivers vs. Katz decision (6), all nonemergency decisions about the involuntary administration of antipsychotic drugs to committed patients must be made by a judge. So the city returned to court for the third time, seeking judicial authorization to administer a three-week trial of haloperidol. The remainder of this paper concerns this attempt to involuntarily medicate Joyce Brown.

Joyce Brown's illness. In Joyce Brown's commitment hearing and the hearing about her involuntary medication, the court approached the problem by first attempting to determine the extent of Miss Brown's mental illness. However, her case was especially perplexing because a satisfying answer to this question was to remain permanently beyond reach.

Miss Brown's first known contact with the psychiatric system was a single previous two-week hospitalization in 1985. Her admission diagnosis had been atypical psychosis, rule out paranoid schizophrenia; her discharge diagnosis was paranoid personality disorder. Before that hospitalization, however, she had a 20-year history of drug abuse, including use of cocaine and intravenous heroin. She had worked for many years as a secretary, but stopped working and received Social Security disability benefits after the 1985 hospitalization. She never resumed her previous level of functioning and became homeless in April 1986 , after relatives were no longer able to care for her.

Repeated observations were made during her hospitalizations that Miss Brown was hostile, verbally abusive, socially isolated, and resistant to treatment. Numerous instances of screaming, yelling, cursing, agitation, and threatening physical gestures toward staff and patients were documented. She had appeared similarly belligerent to the mental health workers who observed her on the streets. For example, she cursed at passersby, became angry at offers of help, and exposed her nude buttocks to the outreach psychiatrist. Intermittently she displayed evidence of a thought disorder, such as talking in rhymes and offering irrelevant answers.

However, city psychiatrists were unable to prove convincingly that Miss Brown was psychotic. Her evasive and somewhat incredible explanations for her behavior did 
not provide definitive evidence of the delusions or hallucinations characteristic of psychosis. For example, she burned and tore money with the explanation that the money had been offered in a condescending manner and that, in any case, keeping money on the streets was dangerous. She talked and laughed to herself but denied that she was responding to voices.

Since she was rational and lucid in court, she may have never been seriously psychotic. On the other hand, her psychosis may have improved in the hospital even without medication, or she may in fact have been psychotic but may also have had the desire and ability to conceal her symptoms.

As for the question of her dangerousness, Miss Brown consistently denied suicidal and homicidal ideation. She explained that her inadequate clothing and hygiene were the consequences of poverty and homelessness. She denied that she had been trying to harm herself during the one occasion when Project HELP staff observed her walking into traffic. She stated that her resort to verbal abuse was necessary to fend off unwanted offers of help.

Joyce Brown's capacity. While it wasn't possible to determine the precise extent of Miss Brown's mental illness, the Rivers decision offered a way to arrive at a decision about involuntary medication by weighing other issues. According to Rivers, the legal standard for authorizing involuntary treatment involves two elements.

First, the state must demonstrate "by clear and convincing evidence" the patient's incapacity to make a treatment decision. In the absence of such incapacity, the patient has the right to refuse treatment, no matter how beneficial. Second, if the patient is determined to lack capacity, the state must show that "the proposed treatment is narrowly tailored to give substantial effect to the patient's liberty interest, taking into consideration all relevant circumstances, including the patient's best interests, the benefits to be gained from the treatment, the adverse side-effects associated with the treatment, and any less intrusive alternative treatments" (6).

If Miss Brown had the capacity to make her own treatment decision, she clearly had the right to refuse medication. In considering her case, the distinction between

\section{Too little is known \\ to conclude that a \\ course of medication \\ in the hospital \\ leads to long-term \\ improvement and \\ compliance after \\ discharge.}

a mental status examination, intended to provide a global picture of the patient's psychiatric functioning, and an assessment of capacity, which is a more narrowly focused evaluation, becomes important. This distinction is frequently overlooked by clinicians (McKinnon K, Cournos F, Stanley B, unpublished paper, 1989).

Many authors in the legal and psychiatric literature have accepted a definition of capacity based on four tests that form a hierarchy. Each of the four tests provides a stricter standard of decisionmaking ability. These four tests are evidencing a choice, factual understanding of the choice, rational reasoning, and appreciation $(7,8)$.

Miss Brown was able to pass the first three tests of capacity. She knew she had a decision to make concerning her treatment. Her knowledge of the proposed medication rivaled that of a firstyear psychiatric resident. She knew the name, class, side effects, and purpose of the proposed drug. The reasons she offered for refusing the medication were rational and nonpsychotic. She doubted its effectiveness in her case, disliked the side effects, and was wary of all mind-altering drugs because of her past history of addiction.
However, Miss Brown failed the last and strictest test of capacity, appreciation. Both the city and the NYCLU agreed that Miss Brown had impaired insight and poor judgment about the consequences of her behavior. She viewed all of her own actions as a realistic response to external circumstances and could not understand why others would attempt to forcibly treat her.

This brings us to an interesting point-capacity is not an all-ornothing phenomenon. At the extremes, capacity requires as little as a patient's ability to offer a yes-or-no answer to a proposed treatment or as much as an assurance that no pathological emotional or motivational pressures influence his decision $(9,10)$.

The Rivers decision suggests that when capacity is present, the court need not examine the merits of treatment. In these instances, only the patient, applying his own values, can determine if the treatment proposed for him is appropriate. In practice, however, capacity cannot be examined separately from the proposed treatment because tests of capacity are adjusted to the risk-benefit ratio of the intervention under consideration (11). If the benefits are limited, such as taking aspirin for a headache, or the risks are great, such as accepting a heart transplant, very little capacity is needed to successfully refuse treatment. Therefore, whether Miss Brown had sufficient capacity to refuse an antipsychotic drug depended in part on the benefits and risks of drug treatment in her case.

Benefits of treatment. The city acknowledged that Miss Brown's behavior had become more organized within the first few days of hospitalization and that her situation was not acute. Therefore, the benefits of medication would not be in managing a crisis, but rather in treating an ongoing condition.

Miss Brown had clearly been chronically hostile, irritable, and verbally abusive. In unstructured situations she often behaved in a 
primitive, regressed, and socially aberrant manner. She appeared to provide incomplete information about her internal state, but the behavioral picture was compatible with a diagnosis of a serious mental illness, either schizophrenia or manic-depressive disease. Miss Brown had never received an adequate course of antipsychotic drugs, whose likely benefits would be to diminish her symptoms and improve her functioning. Moreover, no alternative treatments were available that would be likely to ameliorate her symptoms.

The city lawyers had emphasized Miss Brown's potential dangerousness. Reducing dangerousness often weighs heavily in a court's consideration of a treatment's benefits. Yet the evidence for signifcant danger to herself or others was weak.

Risks of treatment. In examining risk, courts primarily take into account the serious side effects of psychotropic medications. Many courts have emphasized the intrusive nature of these medications. The court's focus on risks is in obvious contrast to that of physicians, who emphasize the benefits of treatment (12).

Moreover, since antipsychotic drugs ameliorate symptoms rather than cure illness, the risks of side effects extend over the indefinite period of time that the drugs must be used. Another risk is that coercion may result in short-term treatment at the cost of the patient's long-term cooperation. Physicians maintain the hope that refusal of treatment is a symptom, which will improve along with the illness itself. However, too little is known to conclude that a course of involuntary medication in the hospital leads to long-term improvement and compliance after discharge (13). When the patient does not ultimately agree that the treatment was beneficial, he may be resentful and reluctant to have further contact with the mental health system.

How did these issues apply to Miss Brown's case? Little was known about Miss Brown's response to medication. Her total exposure to antipsychotic drugs involved a single emergency dose of $5 \mathrm{mg}$ of intramuscular haloperidol on the day of admission to Bellevue and brief treatment with chlorpromazine during her 1985 hospitalization. She reported that these medications were very unpleasant; they made her feel sleepy, light-headed, and less able to think. She connected this dysphoric response to unpleasant memories of her long period of drug addiction. Moreover, she prided herself on her independence. Her stubborn refusal to accept medication could thus have been characterological and not based on her primary mental illness.

Timing of treatment. Miss Brown's condition was neither recent nor emergent, and therefore a separate question arose about delaying a course of medication. Miss Brown had constructed a discharge plan of her own, which included residing in a Midtown hotel and receiving various kinds of practical help from her lawyers. The less aggressive option could be tried first, with the understanding that the more intrusive treatment-medication-could be undertaken later if these conservative measures failed.

The consultant's recommendation. As independent psychiatric consultant, I based my recommendations on the finding that Joyce Brown had partial capacity to make the treatment decision. I believed that Miss Brown had a mental illness that would benefit from medication and that there were no less intrusive treatments that were likely to be effective. Miss Brown engaged in risk-taking behaviors, but neither she nor others had come to serious physical harm in the past, and the risks she took were not extreme.

I believed that Miss Brown's antipathy to treatment was likely to be increased by coercion and that she would discontinue the medication once she left the hospital. She would therefore be likely to have significant difficulties after discharge with or without a course of medication in the hospital.

Given Miss Brown's fairly good capacity and the moderate riskbenefit ratio of involuntarily administered antipsychotic drugs, I recommended that Miss Brown attempt her own discharge plan without receiving medication. If she required rehospitalization, perhaps a better case could be made at that time that medication was necessary to her survival in the community.

The judge's ruling. On January 15, 1988, Judge Irving Kirschenbaum and I deliberated for over two hours, carefully contrasting the possible outcomes of medicating Joyce Brown with the possible consequences of allowing her to leave the hospital without having been medicated. The Judge and I reached a consensus that Miss Brown's refusal of medication should be supported. Taking into account my findings, Judge Kirschenbaum ruled that Joyce Brown had the capacity to make a reasoned decision and upheld her wish to refuse medication (14). He cited her rational objections to medication and the lack of convincing evidence for dangerousness. He was not persuaded that the medical benefits would outweigh the negative effects of a course of involuntarily administered haloperidol.

Hospital discharge. Four days later, after a 12-week hospital stay, her treating physician discharged Miss Brown, stating that without medication she would receive no further benefit from continued hospitalization (15). Miss Brown moved into a room in a Midtown Manhattan residence for homeless women that offers onsite meals and the services of a mental health team.

In the months after her discharge, the press continued to report the apparently contradictory aspects of her behavior. For example, she was a guest speaker at Harvard Law School on February 18,1988 , but two weeks later she was panhandling and cursing on the streets (16). She was arrested for heroin possession in Septem- 
ber 1988 and in January 1989 she was reported to be temporarily back on her accustomed street corner (17).

\section{Discussion}

Joyce Brown's case illustrates some of the ongoing controversies about the use of coercion in response to treatment refusal. In New York State, as in almost all other states (18), an incompetent refusal of treatment is not required for commitment. A standard requiring incompetent refusal of treatment for commitment is found in the APA model law on civil commitment, and its application might significantly restrict the number of patients who could be committed (19).

Miss Brown's refusal of medication was upheld based on her rational and lucid testimony. This result is uncommon among committed patients. However, if commitment required the incompetent refusal of treatment, such a situation would be even less likely to occur. But problems would remain, including the definition of capacity and the fluctuations in any particular patient's capacity. Such problems are apparent in Miss Brown's case because her capacity appeared to improve between the time of her commitment and the court hearing about her medication.

The Brown case also tells us about the limits of coercion in a mental health system that has shifted the locus of care from the hospital, where involuntary treatment is readily undertaken, to residential and outpatient care, where patient cooperation and responsibility are essential. Such a system is poorly equipped to respond to large numbers of individuals who are unable to accept needed services.

Committed patients have their objections to medication overridden 67 to 100 percent of the time (13). While it is easy to win the battle over medication with a hospitalized patient, the same patient can almost always avoid treatment after discharge. Noncompliance rates among outpatients who take antipsychotic drugs exceed 40 percent (20).

Therefore it is misleading to view treatment objections solely from an inpatient perspective. Even if Miss Brown had been involuntarily medicated, she would still have been free to decide about her own treatment after leaving the hospital. If Miss Brown indeed had a life-long illness such as schizophrenia, a short-term solution was less important than a long-term plan. Persistent medication refusal among the seriously mentally ill can result from impairments in the capacity for selfobservation (the appreciation standard of capacity), co-morbidity with substance abuse or character pathology, a poor therapeutic response to drugs (21), and intolerable side effects of medication (22). These problems have no simple solutions. Long-term efforts are required to engage patients in treatment and find acceptable strategies for their care (23).

Miss Brown's dramatic hospitalization and the accompanying events were temporarily effective in allowing her to accept placement in a home. Eliciting more complete and longer-term cooperation is another matter. In this regard, the unusually articulate Miss Brown typifies the problems of the disaffiliated homeless.

\section{Acknowledgments}

The author thanks Stephan Haimowitz, J.D., and Karen McKinnon, M.A.

\section{References}

1. Barbanel J: Mentally ill homeless taken off New York Streets. New York Times, Oct 29, 1987, p Al, B9

2. James G: Burning dollar bills on the sidewalk. New York Times, Oct 29, 1987, p B9

3. Brooks $\mathrm{AD}$ : Law and ideology in the case of Billie Boggs. Journal of Psychosocial Nursing 26:22-25, 1988

4. Matter of Boggs, 136 Misc 2d 1082 (New York, 1987)

5. Boggs v Health and Hospitals Corp, 132 AD 2d 340 (New York, 1987)

6. Rivers v Katz, 67 NY 2d 485, 495
NE 2d 337, 343, 504, NYS 2d 74, 80 (1986)

7. Sullivan TM: The involuntarily confined mental patient and informed consent to psychiatric treatment. Loyola University Law Journal 5:578-609, 1974

8. Appelbaum PS, Roth LH: Competency to consent to research: a psychiatric overview. Archives of General Psychiatry 39:951-958, 1982

9. Stanley B: Informed consent in treatment and research, in Handbook of Forensic Psychology. Edited by Weiner I, Hess A. New York, Wiley, 1987

10. Michels R: Competence to refuse treatment, in Refusing Treatment in Mental Institutions: Values in Conflict. Edited by Doudera AE, Swazey JP. Ann Arbor, Mich, Association of University Programs in Health Administration Press, 1982

11. Roth LH, Meisel A, Lidz CW: Tests of competency to consent to treatment. American Journal of Psychiatry 134:279-284, 1977

12. Appelbaum PS, Hoge SK: The right to refuse treatment: what the research reveals. Behavioral Sciences and the Law 4:279-292, 1986

13. Brooks AD: The right to refuse antipsychotic medications: law and policy. Rutgers Law Review 39:339-376, 1987

14. In re Sabatini ex rel Joyce Brown, No 95656-87 (Sup Ct NY 6, Jan 15, 1988)

15. James G: Joyce Brown, hopeful, savors her new world. New York Times, Jan 20, 1988, p B2

16. Kasindorf J: The real story of Billie Boggs. New York Magazine, May 2, 1988, pp 36-44

17. Seifman D, Pessin E: Billie Boggs goes back to streets. New York Post, Jan 28, 1989, p 5

18. Simon RI: Clinical Psychiatry and the Law. Washington, DC, American Psychiatric Press, 1987

19. Hoge SK, Appelbaum SP, Greer A: An empirical comparison of the Stone and dangerousness criteria for civil commitment. American Journal of Psychiatry 146:170-175, 1989

20. Young JL, Zonana HV, Shepler LS: Medication noncompliance in schizophrenia: codification and update. Bulletin of the American Academy of Psychiatry and the Law 14:105-122, 1986

21. Van Putten T, Crumpton E, Yale C: Drug refusal in schizophrenia and the wish to be crazy. Archives of General Psychiatry 33:1443-1446, 1976

22. Van Putten $T$ : Why do schizophrenic patients refuse to take their drugs? Archives of General Psychiatry 31:6772, 1974

23. Sarti P, Cournos F: Medication and psychotherapy in the treatment of chronic schizophrenia. Psychiatric Clinics of North America (in press) 